MARTIN STARČEVIĆ, Ph.D. ${ }^{1}$

(Corresponding author)

E-mail: martin.starcevic@fpz.hr

DANIJELA BARIĆ, Ph.D. ${ }^{1}$

E-mail: danijela.baric@fpz.hr

HRVOJE PILKO, Ph.D. ${ }^{1}$

E-mail: hrvoje.pilko@fpz.hr

1 University of Zagreb,

Faculty of Transport and Traffic Sciences

Vukelićeva 4, 10000 Zagreb, Croatia
Safety and Security in Traffic

Preliminary Communication

Submitted: July 4, 2016

Accepted: Nov. 16, 2016

\title{
SURVEY-BASED IMPACT OF INFLUENCING PARAMETERS ON LEVEL CROSSINGS SAFETY
}

\begin{abstract}
Level crossing (LC) accidents are a significant safety challenge worldwide and for that reason they have been subject of numerous research activities. Joint conclusion is that human behaviour is the main cause of accidents. This study examines how and to which extent certain influential parameters cause accident mechanisms on level crossings. To gain the necessary data we used an on-line survey questionnaire that was sent internationally to key experts in the field of road and railway safety. A total of 185 experts were asked to rank how much certain parameters influence level crossings accident mechanisms and what are the best countermeasures for diminishing accidents at level crossings. To our knowledge, this is the first time that an international survey among key experts was used to gain necessary data about influential parameters regarding level crossings safety. The results of this study could be used by road and railway traffic engineers and policy makers for further enhancement of LC's safety.
\end{abstract}

\section{KEY WORDS}

level crossings; influential parameters; accident mechanisms; safety challenge; human behaviour; expert survey; countermeasures;

\section{INTRODUCTION}

Level crossings (LC) are places where roads cross railway lines or industrial tracks, i.e. from the aspect of construction, a place of crossing of the road pavement surface and the running surface of the rail [1]. As such, they represent a significant safety challenge due to complex sociotechnical systems which involve interactions between many different types of road users (pedestrians, cyclists, motor vehicle drivers) and railway operators (train drivers, signal operators) and infrastructure (protection systems) [2]. For that reason, level crossings need to be properly marked and protected with appropriate protection systems. Basic classification of level crossings protection systems is divided into passive and active ones $[3,4]$. With passive systems the road user is solely responsible for observing the traffic situation (approaching train). Road traffic signs used for passive level crossings (traffic signs "Stop" and "St. Andrews Cross") stay unchanged and the users have to understand what they mean, then search/listen for trains, and respond accordingly to the observed traffic situation. On the other hand, active protection changes its state to warn road users of approaching train (flashing light and sound and/or full or half barriers) [3, 4].

Level crossings safety varies depending on the country, so for example, there are 211,893 LCs in USA on $228,218 \mathrm{~km}$ of railway tracks [5]. There were 1,233 fatalities between 2010 and 2014 on 10,493 LC's accidents which represents $34.7 \%$ of all railway-related fatalities $(3,558)$ in the USA [6]. India has 30,348 LCs on $65,436 \mathrm{~km}$ of railway tracks with very poor traffic culture. Accidents at LCs represent $43 \%$ of all railway-related accidents in India with $67 \%$ of all fatalities [7]. In Australia there are 23,532 LCs with a yearly average of 78 accidents and 38 fatalities which is the largest cause of Australian rail-related fatalities. Only $33 \%$ of LCs in Australia have active protection systems [8].

In the European Union (EU) there are 114,120 level crossings on $213,910 \mathrm{~km}$ of railway tracks, out of which 51\% have passive and the remaining 49\% have active protection systems. There was a total of 11,991 railway-related accidents in the EU between 2010 and 2014 of which 3,310 were LC accidents. Overall railway traffic saw 5,912 fatalities in the same time span out of which 1,722 were fatalities on level crossings [9]. This is a significant safety challenge for EU railway traffic because fatalities at LCs represent almost 1/3 of all railway-related fatalities. Railway safety in the Republic of Croatia in the same time span is far worse than the EU average. There is a total of 1,520 LCs (62.7\% passive; $37.3 \%$ active) on $2,604 \mathrm{~km}$ of railway tracks. There was a total of 203 LC accidents which is $37.8 \%$ of all railway-related accidents. Between 2010 and 2014 there were 48 people who lost their lives in LC accidents. This is $44 \%$ of all railway-related fatalities in the Republic of Croatia $[10,11]$. 
According to the results of SELCAT (Safer European Level Crossing Appraisal and Technology) project the causes of $\mathrm{LC}$ accidents can be divided into five categories: 1. Road-side human causes; 2. Rail-side human causes; 3 . Road-side technical causes; 4 . Railside technical causes; and 5. Other causes. Further project results showed that about $91 \%$ of all accidents in the EU are caused by human failures, out of which more than $80 \%$ were caused by the road vehicle driver not obeying traffic rules [3]. Furthermore, human failures are caused by certain accident mechanisms which are grouped into three categories: (1) where the level crossing user is unaware of the dangerous situation (non-visible traffic signs, in-vehicle distraction, external distraction, knowledge gap of traffic rules and railway vehicles characteristics); (2) where the level crossing user is unable to avoid the dangerous situation (speeding, weather conditions, pavement quality, road and rail geometry...), and (3) where the level crossing user is unwilling to recognize the dangerous situation (intentional violations) [12]. Each of these accident mechanisms are caused by influential parameters which have direct impact on human behaviour.

The aim of this paper is to gain knowledge of how much certain influential parameters have impact on level crossing accident mechanisms and what is the most effective safety measure to prevent inappropriate human behaviour. The survey questionnaire among key international experts was to be used to obtain the necessary data. Key experts included road and railway traffic and civil engineers, policy makers, academic scholars and other experts in the field of road and railway safety.

The paper continues as follows. Section 2 considers current research of level crossings safety. Section 3 explains the methodology of this paper. Section 4 presents the results of the survey questionnaire. Section 5 summarizes the key results and provides further recommendations.

\section{BACKGROUND}

Level crossings create serious potential conflict points for collisions between road users and trains and therefore present a worldwide safety challenge, which increasingly attracts the attention of the public, rail industry and relevant transport authorities [13]. There are three categories regarding level crossing safety research: national and international safety programs, educational campaigns, and technical solutions [14] but they cannot be studied individually. According to [15] safety at level crossings can be improved by actions characterized as 3E (Engineering, Education and Enforcement) which Nelson [16] expanded as 5E (Enabling, Education, Engineering, Enforcement and Evaluation). This principle states that there is equal importance in the cooperation between road and railway sector, continuous education of level crossing users (motor vehicle drivers, cyclists and pedestrians), new technical solutions for level crossing protection systems and evaluation of effectiveness of implemented safety measures.

Since behaviour of road users is the main cause of accidents at level crossings some studies tried to find out the reasons for such behaviour. In Australia it was found that almost half of all LC accidents happened when the drivers failed to detect warnings, failed to comprehend their meaning or misjudged the speed of an oncoming train while entering the LCs [17]. A study in New Zealand using simulator showed that the reason behind misjudging speed of approaching train is due to a size-speed illusion. This states that a large object seems to be moving slower than a smaller object travelling at the same speed and that puts the level crossing users at considerable risk [18]. Another study in Australia among 636 pedestrians found that $24.52 \%$ of them deliberately violated the rules at level crossings (the main reason was "being in a rush"), while $18 \%$ were either unsure or did not when it was legal to cross at a level crossing [19]. Some authors [20] compared driver behaviour at LCs with two different active protection systems by secretly used video cameras to observe driver behaviour. They concluded that the drivers are more reluctant to engage in risky behaviour when they have a physical barrier in front of them instead of just flashing lights. Another study [13] compared the driver behaviour between passive and two types of active protection systems. They concluded that drivers at passive LCs are more attentive because they scan for train information, whereas this information is readily available at active LCs. This study also found a weakness of passive systems in obtaining drivers' respect in compliance and slower reaction to reduce speed.

Using a driver simulator studies in Australia compared the driver response to three different ITS (Intelligent Transport Systems) interventions designed to enhance driver behaviour at LCs. They used in-vehicle visual ITS in form of a smartphone, audio ITS device to provide verbal messages to drivers and road-based ITS system using flashing warning beacons. The results of the study indicated that drivers intended to use all three interventions, with the highest acceptance for the road-based ITS system at passive crossings [21]. Driver distraction is among the leading parameters for increased risk of traffic accidents and according to one study [22] there are increased in-vehicle distracting parameters among drivers. In this study during a seven-day secret roadside observation among a total of 10,984 drivers, $16.8 \%$ of them were engaged in some kind of distraction, mostly conversation and turning towards passengers and using mobile phones. Some authors [23] found that hands-free distracting tasks can increase risk for accident involvement such as mind-wondering. This entails a failure to scan or monitor the environment, and in case of level crossings, not to recognize the protection systems in time. Another 
study [24] found that familiar and accepted activities (listening to radio and conversation with passengers) are associated with slower reaction times and higher accident risks. In the USA the studies determined that speeding is the major contributing factor leading to higher crash severity especially in bad weather conditions. Their study concluded that high vehicle speed increases the likelihood of fatality by $132 \%$ under fog conditions, $118 \%$ under snow conditions, $98 \%$ under rain conditions, $88 \%$ under cloudy conditions, and $65 \%$ under clear weather conditions [25].

There is a lot of emphasis on national programs and educational campaigns such as Operation Lifesaver in the USA [26,27] and ILCAD - International Level Crossing Awareness Day [28]. Their main purpose is to increase road user's awareness by providing educational lectures and workshops, round tables, creating multimedia games, posting educational posters and influencing social media. Such campaign also exists in the Republic of Croatia since 2000 when the Croatian railways started their campaign "Vlak je uvijek brži" (Eng.: Train is always faster") [29] in elementary schools. It included lectures, educational posters and pamphlets and since then expanded on all level crossing users as well as on social networks.

Yet another approach is to implement new and innovative technical means in order to prevent road users' intentional or unintentional rules braking. Some authors [30] suggest advanced scanning and road vehicle license plates recognition systems which are directly connected with appropriate law enforcement agencies. This could lead to better statistical analysis of drivers who are intentionally bypassing LC protection systems and also repression measures could be enforced based on video evidence. In order to influence the drivers' behaviour in approach to LC implementation of special reflective signs embedded into pavement and rumble strips are suggested by some authors [31]. Some studies showed that implementation of countdown displays for pedestrians have significant effect on total number of violations, regardless of its location and traffic flow [32]. Also, instalment of median barriers on LCs with half-barriers could prevent drivers from going around the lowered barriers [33].

\section{METHODOLOGY}

In order to gain relevant data about influential parameters that affect accident mechanisms on level crossings an international survey was conducted among key experts. In some studies regarding data gathering from targeted experts, the questioners were part of specifically designed websites [34]. Others used paper questioners where interviewers went directly to targeted experts' workplaces [35] and some used oral interviews with prepared questions [36]. Some used Web-based Google Forms tool [37] which were then sent directly to targeted experts. In some cases, the studies in the United Kingdom used written questionnaires simultaneously to two independent groups: targeted experts in transport field and random members of the public in order to compare discrepancies between two groups [38]. Some studies used short invitations to targeted experts for on-line survey on social networking forums and general interest groups on Facebook and Twitter [39].

In this study Google Forms tool was used for developing a questionnaire after which a survey link was sent by e-mail to the targeted key experts. The link was open for 60 days from November 24, 2014 until January 24, 2015.

International experts were identified through scientific papers published in relevant journals indexed in ScienceDirect, IEEE Xplore Digital Library and ISI Web of Science and list of speakers from numerous scientific conferences regarding level crossing safety. There were 135 successfully delivered survey questionnaires to international experts (50 emails were returned due to invalid or expired addresses). Targeted key experts in the field of road and railway safety in the Republic of Croatia were employees of Railway and Road Transport Department of the Faculty of Transport and Traffic Sciences, Road Department of the Faculty of Civil Engineering, Railway Project Company engineers, as well as employees from the Croatian Railways, the Croatian Roads Company and the Ministry of Internal Affairs. The total number of successfully delivered survey questionnaires to the targeted experts in the Republic of Croatia was 50.

In total, 185 survey questionnaires were successfully delivered to the international and national safety experts with expected confidence level of 95\% and margin of error at 10\%; a representative sample of 64 surveyed experts were calculated, which represents $34.6 \%$ of the total number of successfully delivered survey questionnaires [40]. The total number of answered questionnaires was 75 which represents $40.5 \%$ of the total number of successfully delivered survey questionnaires.

The first part of the survey contained general demographic questions about gender, age, country of residence, workplace, years of working at the current job and to which extent their current job descriptions affect issues regarding level crossings safety.

The second part of the survey consisted of six specific questions where experts had to rank the offered answers in order of importance (1 the least important, 5 the most important). The first question was about the importance of level crossings protection systems with five offered answers (passive protection; manned full barrier; flashing lights and sound; flashing light and sound with half-barrier; flashing lights and sound with full barrier). In the second, third and fourth questions the experts had to rank the influential parameters that could cause accident mechanisms. The offered answers according to type of accident mechanisms can be seen in Table 1. 
Table 1 - List of influential parameters according to accident mechanisms

\begin{tabular}{|c|c|}
\hline Accident Mechanisms & Influential Parameters \\
\hline \multirow{5}{*}{$\begin{array}{l}\text { Level crossing user is unaware of the } \\
\text { dangerous situation }\end{array}$} & $\begin{array}{l}\text { Advance warning signs were not visible due to vegetation, damage or they were } \\
\text { "drowned" among other signs }\end{array}$ \\
\hline & $\begin{array}{l}\text { Existence of objects outside vehicle that can cause driver distraction advertising } \\
\text { billboards, other traffic signs, pedestrian traffic, etc.) }\end{array}$ \\
\hline & $\begin{array}{l}\text { In-vehicle distraction (cell phones, managing stereo systems, conversation with } \\
\text { passengers, attending to children, etc.) }\end{array}$ \\
\hline & Not knowing traffic rules for level crossings \\
\hline & $\begin{array}{l}\text { Not knowing characteristics of train movement (unable to stop, long stopping } \\
\text { distance) }\end{array}$ \\
\hline \multirow{8}{*}{$\begin{array}{l}\text { Level crossing user is unable to avoid } \\
\text { the dangerous situation }\end{array}$} & Driving too fast on approach to level crossing \\
\hline & Bad pavement condition on approaching roads \\
\hline & Steep road gradient on approach to level crossing \\
\hline & Bad weather conditions (rain, hail, snow, fog, ice) \\
\hline & Miscalculation of train speed \\
\hline & Crossing angle between road and railway tracks \\
\hline & Sun glare \\
\hline & Number of railway tracks \\
\hline \multirow{5}{*}{$\begin{array}{l}\text { Level crossing user is unwilling to } \\
\text { recognize the dangerous situation }\end{array}$} & Familiarity with level crossings protection systems (daily usage) \\
\hline & Level crossing closure time \\
\hline & Time between start of the warning signal and actual train arrival at crossing \\
\hline & Lack of police surveillance at level crossing sites \\
\hline & Lack of appropriate repression measures \\
\hline
\end{tabular}

In the fifth question the experts had to rank the offered countermeasures (Table 2) for reducing accidents at level crossings. Grade separation was excluded from the answers as the most obvious final solution.

At the end of the questionnaire the experts were asked to identify in their own words any (previously not mentioned) countermeasures that could in their opinion, reduce the number of accidents on level crossings.

Table 2 - List of possible countermeasures

\begin{tabular}{||l||}
\hline \multicolumn{1}{|c||}{ Offered Countermeasures } \\
\hline \hline Upgrading the level of protection systems \\
\hline Continuous education campaign \\
\hline Permanent video surveillance \\
\hline Increased repression measures \\
\hline Removal of objects that can influence sighting distances \\
\hline Implementing rumble strips \\
\hline Removal of objects that can cause driver distraction \\
\hline Lowering car speed limits \\
\hline $\begin{array}{l}\text { Adjusting level crossing closure times due to different } \\
\text { train speeds }\end{array}$ \\
\hline $\begin{array}{l}\text { Train vehicle light and sound signalling when approaching } \\
\text { the level crossing (with any level of protection) }\end{array}$ \\
\hline $\begin{array}{l}\text { Increasing the visual appearance of advance warning } \\
\text { signs }\end{array}$ \\
\hline
\end{tabular}

\section{SURVEY RESULTS}

Out of 75 surveyed experts 62 were males (83\%) and the remaining 13 females (13\%). Analysing age distribution, $28 \%$ of experts were between 51 and 60 years old, followed by $23 \%$ of experts between 31 and 40 , and $21 \%$ of experts between 41 and 50 years of age. There were $19 \%$ of experts in the age group of over 60 years of age and only $9 \%$ of experts under the age of 30 .

The majority of experts' home residence is the United States of America (28), followed by Croatia with 24 surveyed experts. The United Kingdom and Australia followed with five and Finland, Germany and Canada with two experts each. Seven remaining countries had one surveyed expert each (Belgium, France, Hungary, Serbia, Slovenia, Sweden and Switzerland). Most of the surveyed experts work in educational institutions (25\%) followed by public service institutions (31\%) and railway companies (16\%). The construction companies employ further $12 \%$ of experts followed by experts employed in scientific institutes (4\%). There are $12 \%$ of experts' workplaces that are marked as other. There are $37 \%$ of experts who work at their present jobs for more than 15 years, 32\% between 3 and 8 years, followed by $21 \%$ between 9 and 14 years at the 
current job. Only $10 \%$ work less than 3 years at their current positions. Since the experts were specifically targeted for their expertise in railway safety, it is no surprise that the majority of their job descriptions have extremely strong (43\%) and strong (37\%) effect on the level crossings safety. Moderate effect was declared by $17 \%$ of experts and only $3 \%$ stated that their job description had barely any effect on the issue in hand.

Analysing the answers from the first question about importance of level crossings protection systems it can be concluded that all the experts ranked the protection systems on a similar base, e.g. giving lower rank to passive systems and higher ranks to active protection systems. Not surprisingly more than half of the experts (54.67\%) gave the passive protection the lowest possible rank, but interestingly 11 experts (14.67\%) gave it the highest possible importance. Overall, $72 \%$ of all experts gave the lowest two ranks to passive system, while $89.3 \%$ gave the highest two ranks to active systems using full barrier with flashing lights and sound.

In situations where the level crossing users are unaware of the dangerous situation (Table 3), in the opinion of experts, the main influential factor for causing accident mechanisms is in-vehicle driver distraction where $74.7 \%$ of all experts gave this factor two highest ranks (Table 3c). Closely following is the LC users' knowledge gap of traffic rules (Table 3d) regarding level crossings (60\% experts - two highest ranks). Also, outside distraction objects (Table $3 b$ ) scored relatively high where 39 experts (52\%) gave two highest ranks while another 17 (22.67\%) gave importance rank of 3. Another factor with high importance is the lack of knowledge of train movement characteristics (Table 3e) where 40 experts (53.3\%) gave two highest importance ranks, but 14 experts (18.67\%) think that this factor has the lowest possible importance. Detailed distribution of other influential parameters can be observed in Table 3.

Table 3 - Importance of influential parameters in situations where users are unaware of the dangerous situation

a) Advance warning signs were not visible due to vegetation, damage or they were "drowned" among other signs

\begin{tabular}{|c|c|c||}
\hline Importance & $\begin{array}{c}\text { Number of } \\
\text { experts }\end{array}$ & $\%$ \\
\hline \hline 1 & 12 & 16 \\
\hline 2 & 19 & 25.33 \\
\hline 3 & 7 & 9.33 \\
\hline 4 & 19 & 25.33 \\
\hline 5 & 18 & 24 \\
\hline
\end{tabular}

b) Existence of objects outside vehicle that can cause driver distraction

\begin{tabular}{|c|c|c||}
\hline \hline Importance & $\begin{array}{c}\text { Number of } \\
\text { experts }\end{array}$ & $\%$ \\
\hline \hline 1 & 4 & 5.33 \\
\hline 2 & 15 & 20 \\
\hline 3 & 17 & 22.67 \\
\hline 4 & 26 & 34.67 \\
\hline 5 & 13 & 17.33 \\
\hline
\end{tabular}

c) In-vehicle distraction (cell phones, managing stereo systems, conversation with passengers, attending to children, etc.)

\begin{tabular}{|c|c|c||}
\hline \hline Importance & $\begin{array}{c}\text { Number of } \\
\text { experts }\end{array}$ & $\%$ \\
\hline \hline 1 & 1 & 1.33 \\
\hline 2 & 3 & 4 \\
\hline 3 & 15 & 20 \\
\hline 4 & 23 & 30.67 \\
\hline 5 & 33 & 44 \\
\hline
\end{tabular}

d) Not knowing traffic rules for level crossings

\begin{tabular}{|c|c|c||}
\hline \hline Importance & $\begin{array}{c}\text { Number of } \\
\text { experts }\end{array}$ & $\%$ \\
\hline \hline 1 & 8 & 10.67 \\
\hline 2 & 7 & 9.33 \\
\hline 3 & 15 & 20 \\
\hline 4 & 17 & 22.67 \\
\hline 5 & 28 & 37.33 \\
\hline
\end{tabular}

e) Not knowing characteristics of train movement (unable to stop, long stopping distance)

\begin{tabular}{|c|c|c||}
\hline \hline Importance & $\begin{array}{c}\text { Number of } \\
\text { experts }\end{array}$ & $\%$ \\
\hline \hline 1 & 14 & 18.67 \\
\hline 2 & 8 & 10.67 \\
\hline 3 & 13 & 17.33 \\
\hline 4 & 16 & 21.33 \\
\hline 5 & 24 & 32 \\
\hline
\end{tabular}

In situations where level crossing users were not able to avoid the dangerous situations the highest ranks were given to speeding when approaching the level crossing (68\% of experts gave two highest ranks) (Table 4a), followed by miscalculation of approaching train speed (65\% of experts) (Table $4 \mathrm{f})$. Also, more than half $(57.3 \%)$ of experts think that the crossing angle between road and railway tracks is important and the most important influential factor for causing accident mechanisms (Table 4g). Surprisingly, bad weather conditions are not a significant influential factor (Table 4e) where only 14 experts gave it the highest rank of importance, while 21 experts (28\%) gave the importance 
rank of 3 and 4 , followed by 17 experts (23\%) with importance rank of 2. Detailed distribution of importance of all other parameters is shown in Table 4.

Table 4 - Importance of influential parameters in situations where users are unable to avoid a dangerous situation

a) Driving too fast on approach to level crossing

\begin{tabular}{|c|c|c||}
\hline Importance & $\begin{array}{c}\text { Number of } \\
\text { experts }\end{array}$ & $\%$ \\
\hline \hline 1 & 6 & 8 \\
\hline 2 & 6 & 8 \\
\hline 3 & 12 & 16 \\
\hline 4 & 22 & 29.33 \\
\hline 5 & 29 & 38.67 \\
\hline
\end{tabular}

b) Number of railway tracks

\begin{tabular}{|c|c|c||}
\hline Importance & $\begin{array}{c}\text { Number of } \\
\text { experts }\end{array}$ & $\%$ \\
\hline \hline 1 & 16 & 21.33 \\
\hline 2 & 15 & 20 \\
\hline 3 & 20 & 26.67 \\
\hline 4 & 18 & 24 \\
\hline 5 & 6 & 8 \\
\hline
\end{tabular}

c) Bad pavement condition on approaching roads

\begin{tabular}{|c|c|c||}
\hline Importance & $\begin{array}{c}\text { Number of } \\
\text { experts }\end{array}$ & $\%$ \\
\hline \hline 1 & 18 & 24 \\
\hline 2 & 17 & 23 \\
\hline 3 & 23 & 30.67 \\
\hline 4 & 12 & 16 \\
\hline 5 & 5 & 6.67 \\
\hline
\end{tabular}

d) Steep road gradient on approach to level crossing

\begin{tabular}{||c|c|c||}
\hline Importance & $\begin{array}{c}\text { Number of } \\
\text { experts }\end{array}$ & $\%$ \\
\hline \hline 1 & 7 & 9.33 \\
\hline 2 & 17 & 22.67 \\
\hline 3 & 24 & 32 \\
\hline 4 & 21 & 28 \\
\hline 5 & 6 & 8 \\
\hline
\end{tabular}

e) Bad weather conditions (rain, hail, snow, fog, ice)

\begin{tabular}{|c|c|c||}
\hline Importance & $\begin{array}{c}\text { Number of } \\
\text { experts }\end{array}$ & $\%$ \\
\hline \hline 1 & 2 & 2.67 \\
\hline 2 & 17 & 23 \\
\hline 3 & 21 & 28 \\
\hline 4 & 21 & 28 \\
\hline 5 & 14 & 18.67 \\
\hline
\end{tabular}

f) Miscalculation of train speed

\begin{tabular}{|c|c|c||}
\hline Importance & $\begin{array}{c}\text { Number of } \\
\text { experts }\end{array}$ & $\%$ \\
\hline \hline 1 & 3 & 4 \\
\hline 2 & 12 & 16 \\
\hline 3 & 11 & 14.67 \\
\hline 4 & 21 & 28 \\
\hline 5 & 28 & 37.33 \\
\hline
\end{tabular}

g) Crossing angle between road and railway tracks

\begin{tabular}{||c|c|c||}
\hline \hline Importance & $\begin{array}{c}\text { Number of } \\
\text { experts }\end{array}$ & $\%$ \\
\hline \hline 1 & 3 & 4 \\
\hline 2 & 6 & 8 \\
\hline 3 & 23 & 30.67 \\
\hline 4 & 24 & 32 \\
\hline 5 & 19 & 25.33 \\
\hline
\end{tabular}

h) Sun glare

\begin{tabular}{|c|c|c||}
\hline \hline Importance & $\begin{array}{c}\text { Number of } \\
\text { experts }\end{array}$ & $\%$ \\
\hline \hline 1 & 8 & 10,67 \\
\hline 2 & 21 & 28 \\
\hline 3 & 16 & 21.33 \\
\hline 4 & 20 & 26.67 \\
\hline 5 & 10 & 13.33 \\
\hline
\end{tabular}

Regarding situations where level crossing users were intentionally taking risk actions, the most influential parameters are familiarity with level crossings protection systems (e.g. everyday usage) (Table 5a) and prolonged closure time (Table $5 \mathrm{~b}$ ) which leads to impatient users and thus intentionally breaking of traffic rules. The results have shown that $65.3 \%$ (for familiarity with protection systems) and $69.3 \%$ (for closure time) of experts rank these influential parameters as important and most important.

Furthermore, more than half of the experts (54.7\%) ranked the prolonged time between start of the warning for the approaching train and actual train arriving at the level crossing as important and very important influential factor (Table 5c). Also, the lack of inadequate repression measures have significant impact on level crossing safety, where almost half of the experts (48\%) ranked this factor as important and very important (Table 5e). According to experts the lack of police surveillance at level crossings (Table $5 \mathrm{~d}$ ) does not have such an impact as previous parameters, where only $21.3 \%$ of experts think of this influential factor as most important. Detailed distribution can be observed in Table 5. 
Table 5 - Importance of influential parameters in situations where users were intentionally taking risk actions

a) Familiarity with level crossings (daily usage)

\begin{tabular}{|c|c|c||}
\hline Importance & $\begin{array}{c}\text { Number of } \\
\text { experts }\end{array}$ & $\%$ \\
\hline \hline 1 & 6 & 8 \\
\hline 2 & 5 & 6.6 \\
\hline 3 & 15 & 20 \\
\hline 4 & 22 & 29.33 \\
\hline 5 & 27 & 36 \\
\hline
\end{tabular}

b) Level crossing closure time

\begin{tabular}{|c|c|c||}
\hline Importance & $\begin{array}{c}\text { Number of } \\
\text { experts }\end{array}$ & $\%$ \\
\hline \hline 1 & 2 & 2.67 \\
\hline 2 & 7 & 9.33 \\
\hline 3 & 14 & 18.67 \\
\hline 4 & 29 & 38.67 \\
\hline 5 & 23 & 30.67 \\
\hline
\end{tabular}

c) Time between start of the warning signal and actual train arrival at crossing

\begin{tabular}{|c|c|c||}
\hline Importance & $\begin{array}{c}\text { Number of } \\
\text { experts }\end{array}$ & $\%$ \\
\hline 1 & 3 & 4 \\
\hline 2 & 7 & 9.33 \\
\hline 3 & 24 & 32 \\
\hline 4 & 23 & 30.67 \\
\hline 5 & 18 & 24 \\
\hline
\end{tabular}

d) Lack of police surveillance at level crossing sites

\begin{tabular}{|c|c|c||}
\hline Importance & $\begin{array}{c}\text { Number of } \\
\text { experts }\end{array}$ & $\%$ \\
\hline 1 & 9 & 12 \\
\hline 2 & 14 & 18.67 \\
\hline 3 & 22 & 29.33 \\
\hline 4 & 14 & 18.67 \\
\hline 5 & 16 & 21.33 \\
\hline
\end{tabular}

e) Lack of appropriate repression measures

\begin{tabular}{|c|c|c||}
\hline Importance & $\begin{array}{c}\text { Number of } \\
\text { experts }\end{array}$ & $\%$ \\
\hline 1 & 13 & 17.33 \\
\hline 2 & 9 & 12 \\
\hline 3 & 17 & 22.67 \\
\hline 4 & 13 & 17.33 \\
\hline 5 & 23 & 30.67 \\
\hline
\end{tabular}

Experts were offered 11 different countermeasures for reducing accidents at level crossings and they had to rank them according to the level of influence
(Table 6). Most of the experts agreed that one of the best measures is to increase the protection systems from passive to active where $90.6 \%$ of experts think that upgrading protection systems is of most important and important significance (Table 6a). The second best prevention measure is continuous educational campaign for all level crossing users with $70.6 \%$ of experts ranking this measure as very important (Table 6c). Another measure that experts think has significant influence on diminishing level crossing accidents is increased repression measures in term of higher fines for illegal crossings (e.g. zig-zagging around half-barriers) where $61.3 \%$ gave two highest ranks (Table 6j). The implementation of rumble strips does not seem to have high impact on diminishing accidents since more than one third of experts gave this measure two lowest ranks (36\%) with only 5 experts who gave the highest possible rank (Table 6f). Increasing the visual appearance of advance warning signs as a possible measure scored relatively high among experts where half of them gave two highest ranks (Table 6b). Detailed distribution of respondents for the remaining proposed measures can be observed in Table 6 .

Table 6 - Importance of possible countermeasures

a) Upgrading the level of protection systems

\begin{tabular}{|c|c|c||}
\hline Importance & $\begin{array}{c}\text { Number of } \\
\text { experts }\end{array}$ & $\%$ \\
\hline \hline 1 & 2 & 2.67 \\
\hline 2 & 1 & 1.33 \\
\hline 3 & 4 & 5.33 \\
\hline 4 & 26 & 34.67 \\
\hline 5 & 42 & 56 \\
\hline
\end{tabular}

b) Increasing the visual appearance of advance warning signs

\begin{tabular}{|c|c|c||}
\hline Importance & $\begin{array}{c}\text { Number of } \\
\text { experts }\end{array}$ & $\%$ \\
\hline \hline 1 & 3 & 4 \\
\hline 2 & 13 & 17.33 \\
\hline 3 & 21 & 28 \\
\hline 4 & 28 & 37.33 \\
\hline 5 & 10 & 13.33 \\
\hline
\end{tabular}

c) Continuous education campaign

\begin{tabular}{||c|c|c||}
\hline \hline Importance & $\begin{array}{c}\text { Number of } \\
\text { experts }\end{array}$ & $\%$ \\
\hline \hline 1 & 4 & 5.33 \\
\hline 2 & 6 & 8 \\
\hline 3 & 12 & 16 \\
\hline 4 & 24 & 32 \\
\hline 5 & 29 & 38.67 \\
\hline
\end{tabular}


d) Train vehicle light and sound signalling when approaching the level crossing (with any level of protection)

\begin{tabular}{||c|c|c||}
\hline Importance & $\begin{array}{c}\text { Number of } \\
\text { experts }\end{array}$ & $\%$ \\
\hline \hline 1 & 9 & 12 \\
\hline 2 & 10 & 13.33 \\
\hline 3 & 17 & 22.67 \\
\hline 4 & 25 & 33.33 \\
\hline 5 & 14 & 18.67 \\
\hline
\end{tabular}

e) Removal of objects that can influence sighting distances

\begin{tabular}{|c|c|c||}
\hline Importance & $\begin{array}{c}\text { Number of } \\
\text { experts }\end{array}$ & $\%$ \\
\hline \hline 1 & 1 & 1.33 \\
\hline 2 & 5 & 6.67 \\
\hline 3 & 24 & 32 \\
\hline 4 & 28 & 37.33 \\
\hline 5 & 17 & 22.67 \\
\hline
\end{tabular}

f) Implementing rumble strips

\begin{tabular}{||c|c|c||}
\hline \hline Importance & $\begin{array}{c}\text { Number of } \\
\text { experts }\end{array}$ & $\%$ \\
\hline \hline 1 & 7 & 9.33 \\
\hline 2 & 20 & 26.67 \\
\hline 3 & 27 & 36 \\
\hline 4 & 16 & 21.33 \\
\hline 5 & 5 & 6.67 \\
\hline
\end{tabular}

g) Removal of objects that can cause driver distraction

\begin{tabular}{||c|c|c||}
\hline Importance & $\begin{array}{c}\text { Number of } \\
\text { experts }\end{array}$ & $\%$ \\
\hline \hline 1 & 2 & 2.67 \\
\hline 2 & 11 & 14.67 \\
\hline 3 & 28 & 37.33 \\
\hline 4 & 23 & 30.67 \\
\hline 5 & 11 & 14.67 \\
\hline
\end{tabular}

h) Lowering car speed limits

\begin{tabular}{|c|c|c||}
\hline Importance & $\begin{array}{c}\text { Number of } \\
\text { experts }\end{array}$ & $\%$ \\
\hline 1 & 5 & 6.67 \\
\hline 2 & 20 & 26.67 \\
\hline 3 & 31 & 41.33 \\
\hline 4 & 13 & 17.33 \\
\hline 5 & 6 & 8 \\
\hline
\end{tabular}

i) Permanent video surveillance

\begin{tabular}{|c|c|c||}
\hline \hline Importance & $\begin{array}{c}\text { Number of } \\
\text { experts }\end{array}$ & $\%$ \\
\hline \hline 1 & 5 & 6.67 \\
\hline 2 & 17 & 22.67 \\
\hline 3 & 22 & 29.33 \\
\hline 4 & 15 & 20 \\
\hline 5 & 16 & 21.33 \\
\hline
\end{tabular}

j) Increased repression measures

\begin{tabular}{||c|c|c||}
\hline \hline Importance & $\begin{array}{c}\text { Number of } \\
\text { experts }\end{array}$ & $\%$ \\
\hline \hline 1 & 5 & 6.67 \\
\hline 2 & 10 & 13.33 \\
\hline 3 & 14 & 18.67 \\
\hline 4 & 21 & 28 \\
\hline 5 & 25 & 33.33 \\
\hline
\end{tabular}

k) Adjusting level crossing closure times due to different train speeds

\begin{tabular}{|c|c|c||}
\hline \hline Importance & $\begin{array}{c}\text { Number of } \\
\text { experts }\end{array}$ & $\%$ \\
\hline \hline 1 & 11 & 14.67 \\
\hline 2 & 7 & 9.33 \\
\hline 3 & 11 & 14.67 \\
\hline 4 & 27 & 36 \\
\hline 5 & 19 & 25.33 \\
\hline
\end{tabular}

\section{DISCUSSION AND CONCLUSION}

Level crossings present a serious safety challenge worldwide due to complex sociotechnical systems which involve both different road on the one hand, and railway operators and infrastructure on the other [6-10]. Given the developing trend of level crossing technology to be dominated by active protection systems, it can be assumed that the major cause of LC accidents will continue to be inadequate human behaviour of road traffic users (drivers, cyclists and pedestrians). The aim of this study was to gather data from relevant international key experts to which extent certain parameters influence human behaviour on various accident mechanisms. Online survey questionnaire that was sent to targeted experts was used to obtain necessary data and to our knowledge it is the first of its kind to gather relevant opinions of experts regarding level crossing safety.

The survey was divided in two parts where the first part included demographic data and the second part the specific questions regarding influencing parameters on accident mechanisms. There was a total of 75 successfully completed questionnaires. Most of the 
experts' work positions were in educational institutions, construction companies and public service institutions and since they were specifically targeted it is no surprise that vast majority of their job description is strongly related to level crossings safety.

At the beginning of the second part of the survey, the experts agreed that actively protected LCs are far superior to passive systems and later on concluded that upgrading protection systems from passive to active is among the best measures for reducing the number of accidents at level crossings. According to survey results the main influential factor in situations where road users were unaware of LC's dangers (Table 3) was in-vehicle distraction like handling mobile phones, talking and turning to passengers, tending to children in the back seat and similar. Out of all surveyed experts $74.7 \%$ of them gave this factor two highest possible influence ranks and only $5.3 \%$ of experts the lowest two ranks. This road users' behaviour results in inability to recognize on time the actual LC or its protection systems which then directly leads to a possible accident. Another factor with high influence is the LC's users knowledge gap when it comes to traffic rules regarding level crossings in which $60 \%$ of experts gave two highest ranks. This knowledge gap or lack of proper education also leads to inability to properly asses the characteristics of train movement (lack of manoeuvring abilities, long stopping distances) where more than half of the experts (53.3\%) gave two highest importance ranks.

When it comes to situations where LC's users were not able to avoid already recognized dangerous situation (Table 4), it seems that speeding is the most influential factor (61\% of experts - two highest ranks), followed by miscalculation of approaching train speed (65.3\%) and crossing angle between road and railway tracks (57.3\%). Bad weather conditions do not seem to be very influential factor because only $18.6 \%$ of experts think of this factor as being of the highest importance. The most likely reason for this is the fact that most drivers tend to automatically adjust their driving to weather elements.

Prolonged LC closure (with active protection systems), that leads to LC's users impatience and familiarity with protection systems are among the leading influential parameters for intentionally violating traffic rules at level crossings (Table 5). According to survey results, $69.3 \%$ of experts gave two highest importance ranks to LC closure time and $65.3 \%$ to familiarity with protection systems. Another high ranked factor for active LCs is the time between start of the warning for the approaching train and actual train arriving, which can be in most cases different regarding the speed of the train and that directly leads to drivers' impatience and intentional risk actions. Also, in experts' opinion, lack of inadequate repression measures (low traffic fines) is another high importance factor for intentional risk action on level crossings.

In order to reduce the number of accidents at level crossings, in authors' opinion, there is not one single solution except grade separation. However, because of high cost of such developments it cannot be expected for this to be the final solution for every level crossing in existence but for the few ones with the highest traffic flows and accident history. In order to achieve the highest possible safety level at LCs, different kinds of solutions need to be implemented simultaneously. The survey results (Table 6) showed that the majority of key experts think that upgrading protection systems from passive to active is one of the most important safety measures. Furthermore, even the best technical solution will not suffice if the users do not know or do not want to properly behave when passing an LC. For this reason, continuous educational campaign is crucial for LC safety and where survey results showed that $70.6 \%$ of key experts consider this measure as a very important factor for diminishing LC accidents. Another way to influence irresponsible drivers is to increase repression measures in terms of much higher traffic fines for LC's users' illegal behaviour (zig-zagging around half barriers, not completely stopping at passive LCs) and where $61.3 \%$ of experts gave this measure the highest two ranks (Table 6).

The main limitation of this study is the lack of significant numbers of international key experts within some countries because traffic culture and legal regulations vary from country to country. Furthermore, it is hard to conclude if influence of certain parameters is the same for each country due to different local circumstances. One way to resolve this issue would be to create a survey for each country separately and then compare the results. This could prove to be very important because, to our knowledge, this is the first time that a survey questionnaire was used to gain the key experts' knowledge about influential factors on LC accident mechanisms. This could be a subject for future studies in order to gain even more detailed results about influential parameters and perhaps an introduction to some new ones.

The results of this study as such, could prove useful for road and railway traffic engineers and policy makers for enhancing LC safety by creating custom-tailored prevention measures according to survey results.

\section{ACKNOWLEDGEMENTS}

This study was carried out as part of the scientific project PROM-PRO "Research of Measures to Improve the Safety at Level Crossings - 2nd Phase", funded by the University of Zagreb. Data were collected in collaboration with the Croatian Ministry of Internal Affairs and with the "Vlak je uvijek brži" (Train is always faster) educational program at HŽ-Infrastruktura. 
Dr. SC. MARTIN STARČEVIĆ ${ }^{1}$

E-mail: martin.starcevic@fpz.hr

Dr. sc. DANIJELA BARIĆ ${ }^{1}$

E-mail: danijela.baric@fpz.hr

Dr. Sc. HRVOJE PILKO ${ }^{1}$

E-mail: hrvoje.pilko@fpz.hr

${ }^{1}$ Sveučilište u Zagrebu, Fakultet prometnih znanosti

Vukelićeva 4, 10000 Zagreb, Hrvatska

\section{SAŽETAK}

\section{DEFINIRANJE UTJECAJNIH ČIMBENIKA NA SIGURNOST ŽELJEZNIČKO-CESTOVNIH PRIJELAZA DOBIVENIH ANKETOM STRUČNJAKA}

Nesreće na željezničko-cestovnim prijelazima u svijetu predstavljaju značajan sigurnosni izazov te su zbog toga tema mnogih istraživačkih aktivnosti. Zajednički zaključak svih istraživanja jest u činjenici da je ljudski faktor glavni uzrok svih nesreća. Ovo istraživanje prikazuje na koji način određeni utjecajni čimbenici i u kojoj mjeru utječu na mehanizme nesreća na željezničko-cestovnim prijelazima. Kako bi se prikupili potrebni podaci, provedena je on-line anketa među ključnim stručnjacima iz područja sigurnosti u cestovnom i željezničkom prometu. Ukupno je 185 stručnjaka zatraženo da rangiraju po važnosti utjecaj pojedinih čimbenika na mehanizme nesreća te da odrede najbolje protumjere za smanjivanje nesreća na željezničko-cestovnim prijelazima. Prema našim saznanjima, ovo je prvi puta da se koristi međunarodna on-line anketa ključnih stručnjaka kako bi se dobili potrebni podatci o utjecajnim čimbenicima na sigurnost odvijanja prometa na željezničko-cestovnim prijelazima. Rezultate ovog istraživanja mogli bi koristiti prometni inženjeri cestovnog i željezničkog prometa kao i ostali subjekti koji se bave sigurnošću prometa radi daljnjeg povećanja sigurnosti na željezničko-cestovnim prijelazima.

\section{KLUUČNE RIJEČI}

željezničko-cestovni prijelazi; utjecajni čimbenici; mehanizam nesreća; sigurnosni izazov; ljudsko ponašanje; anketa stručnjaka; protumjere;

\section{REFERENCES}

[1] Toš Z. [Signalizacija u željezničkom prometu]. Zagreb: Faculty of Traffic and Transport Sciences, University of Zagreb; 2013. Croatian.

[2] Read GJM, Salmon PM, Lenn MG. Sounding the warning bells: The need for a systems approach to understanding behaviour at rail level crossings. Appl Ergon. 2013;44(5):764-74. doi:10.1016/ j.apergo.2013.01.007.

[3] Tordai L, Olpinski W, Schafer W, Wegele S. D1 - Report about Statistics, Database Analysis and Regulations for Level Crossing. Paris: SELCAT; 2008.

[4] Starčević M, Barić D, Hozjan D. Safety Analysis at Level Crossings. Proceedings of the ZIRP 2014, 2014 Apr 14; Zagreb, Croatia.

[5] USA. Federal Railroad Administration. Safety data statistics. Available from : http://www.fra.dot.gov/Page/ P0855; 2015.
[6] USA. Federal Railroad Administration. Office of Safety Analysis. Available from: http://safetydata.fra.dot. gov/OfficeofSafety/publicsite/Query/TenYearAccidentIncidentOverview.aspx. 2016.

[7] Pajunen K, Kumar A. Issues Typical to India for Implementation of Level Crossing Safety Programs/Measures. Paper presented at: Best Practices to Improve Level Crossing Safety, UNECE; 2014 October 23-24; Geneve, Switzerland.

[8] Di Millia L, Searle A, Dawson D. An investigation of risk-takers at railway level crossings. Brisbane, Australia: 2012. Available from: www.railcrc.net.au

[9] European Commission Eurostat; [Cited 2016 April 1] Available from: http://ec.europa.eu/eurostat/data/ database.

[10] HŽ Infrastruktura. Godišnje izvješće o sigurnosti u 2014. godini; 2014; Croatian

[11] Starčević M, Barić D, Pilko H. Safety at Level Crossings: Comparative Analysis. Proceedings of the 4th International Conference of. Road and Rail Infrastructure CETRA 2016; 2016 May 23-25; Šibenik, Croatia.

[12] Transport for NSW. ALCAM in Detail 2012. Australia; 2012. Available from: https://alcam.abletech.net.nz/ ALCAM \%282012\%29 - ALCAM in Detail - December 2012.pdf

[13] Tey LS, Ferreira L, Wallace A. Measuring driver responses at railway level crossings. Accid Anal Prev. 2011;43(6):213441. doi:10.1016/ j.aap.2011.06.003.

[14] Badanjak D, Barić D, Novačko L. Priority Measures of Improving Level Crossing Safety. Proceedeings from 11th Int. Conf. Transp. Sci. 2008 May 28-29; Portorož, Slovenia.

[15] Savage I. Does public education improve rail-highway crossing safety? Accid Anal Prev. 2006;38(2):310-6. doi:10.1016/j.aap.2005.10.001.

[16] Nelson A. Level crossings: The-state-of-the-art. Paper presented at: 12th Global Level Crossing Trespass Symposium; 2012 October 7-12; London, UK.

[17] Salmon PM, Read GJM, Stanton NA, Lenné MG. The crash at Kerang: Investigating systemic and psychological factors leading to unintentional non-compliance at rail level crossings. Accid Anal Prev. 2013;50:127888. doi:10.1016/j.aap.2012.09.029.

[18] Clark HE, Perrone JA, Isler RB. Short Communication An illusory size-speed bias and railway crossing collisions. Accid Anal Prev. 2013;55:226-31. doi:10.1016/ j.aap.2013.02.037.

[19] Freeman J, Rakotonirainy A. Mistakes or deliberate violations? A study into the origins of rule breaking at pedestrian train crossings. Accid Anal Prev. 2015;77: 45-50. doi:10.1016/j.aap.2015.01.015.

[20] Meeker F, Fox D, Weber C. A comparison of driver behavior at railroad grade crossings with two different protection systems. Accid Anal Prev. 1997;29(1): 11-6. doi:10.1016/s0001-4575(96)00055-3.

[21] Larue GS, Rakotonirainy A, Haworth NL, Darvell M. Assessing driver acceptance of Intelligent Transport Systems in the context of railway level crossings. Transp Res Part F. 2015; 30:1-13. doi:10.1016/ j.trf.2015.02.003.

[22] Sullman MJM, Prat F, Tasci DK. A Roadside Study of Observable Driver Distractions. Traffic Inj Prev. 
2015;16(6):552-7. doi:10.1080/15389588.2014.98 9319.

[23] He J, Becic E, Lee Y-C, McCarley JS. Mind wandering behind the wheel: performance and oculomotor correlates. Hum Factors. 2011;53(1):13-21. doi: 10.1177/0018720810391530.

[24] Patel J, Ball DJ, Jones H. Factors influencing subjective ranking of driver distractions. Accid Anal Prev. 2008;40(1):392-5. doi:10.1016/j.aap.2007.07.006.

[25] Hao W, Daniel J. Driver injury severity related to inclement weather at highway-rail grade crossings in the United States. Traffic Inj Prev. 2016;17(1):31-8. do i:10.1080/15389588.2015.1034274.

[26] Sramek HM. Operation Lifesaver USA: Transforming for the Digital Age. 1 Paper presented at: 12th Global Level Crossing Trespass Symposium; 2012 Oct 7-12; London, UK.

[27] Operation Lifesaver; c2016. Available from: http:// oli.org/.

[28] ILCAD; c2016. Available from: http://www.ilcad.org/ ILCAD-2013.html.

[29] Vlak je uvijek brži; c2016. Available at: http:// www.hzinfra.hr/akcija-vlak-je-uvijek-brzi. Croatian

[30] Cho BK, Ryu SH, Shin DR, Jung JI. License plate extraction method for identification of vehicle violations at a railway level crossing. Int J Automot Technol. 2011;12(2):281-9. doi:10.1007/s12239.

[31] Tey L-S, Wallis G, Cloete S, Ferreira L, Zhu S. Evaluating Driver Behavior Toward Innovative Warning Devices at Railway Level Crossings Using a Driving Simulator. Transp Saf Secur. 2013;5(2):118-30. doi:10.1080/ 19439962.2012 .731028$.

[32] Lipovac K, Vujanic M, Maric B, Nesic M. The influence of a pedestrian countdown display on pedestrian behavior at signalized pedestrian crossings. Transp
Res Part F Traffic Psychol Behav. 2013;20:121-34. doi:10.1016/j.trf.2013.07.002.

[33] Starčevic M. [Level Crossings Risk Assessment Model] [PhD thesis]. Zagreb, Croatia: University of Zagreb; 2015. Croatian

[34] Escorpizo R, Finger ME, Glässel A, Cieza A. An international expert survey on functioning in vocational rehabilitation using the international classification of functioning, disability and health. J Occup Rehabil. 2011;21(2):147-55. doi:10.1007/s10926-010-9276-y.

[35] Razafindrakoto M, Roubaud F. Are International Databases on Corruption Reliable? A Comparison of Expert Opinion Surveys and Household Surveys in Sub-Saharan Africa. World Dev. 2010;38(8):1057-69. doi:10.1016/j.worlddev.2010.02.004.

[36] Nævestad TO, Phillips RO, Elvebakk B. Traffic accidents triggered by drivers at work - A survey and analysis of contributing factors. Transp Res Part F Traffic Psychol Behav. 2015;34:94-107. doi:10.1016/ j.trf.2015.07.024.

[37] Pilko H. [Optimization of Roundabout Design and Safety Component] [PhD thesis]. Zagreb, Croatia: University of Zagreb; 2014. Croatian

[38] Xenias D, Whitmarsh L. Dimensions and determinants of expert and public attitudes to sustainable transport policies and technologies. Transp Res Part A Policy Pract. 2013;48:75-85. doi:10.1016/ j.tra.2012.10.007.

[39] Piwek L, Joinson A, Morvan J. The use of self-monitoring solutions amongst cyclists: An online survey and empirical study. Transp Res Part A Policy Pract. 2015;77:126-36. doi:10.1016/j.tra.2015.04.010.

[40] Raosoft - sample size calculator; c2016. Available at: http://www.raosoft.com/samplesize.html. http:// www.raosoft.com/samplesize.html. 